\title{
Diversity Management Policy: A Case Study of Formulation Process Joint Ministerial Regulation No. 8 and 9 of 2006 in Indonesia
}

\author{
Muchlis Ari Handy \\ Department of Public Policy Muhammadiyah University of North Maluku \\ KH. Ahmad Dahlan Street No. 100 Ternate City, Indonesia
}

\begin{abstract}
The diversity of the Indonesian people, in the era of reform that has been accompanied by an era of openness, the cause hassle for the government to formulate policies that can accommodate the interests of religious groups, linked to problems concerning the identity and majority-minority relations. One of these policies is the rule with the Minister of Religious Affairs and Minister of the Internal Affairs, No. 8 and 9 of 2006 on the guidelines for regional heads in the management of religious harmony, a form of religious harmony and the establishment of places of worship. It is interesting to observe a policy formulation process that involves policy actors between religious groups, because in some policies regarding the handling of religious life are intended to regulate the diversity that exists in Indonesia, often reap the pros and cons and polemic in society, particularly among religious groups in Indonesia. In the process of policy formulation, there are some components that are believed to influence the formulation process. This component is the environmental policy, policy actors and values surrounding the actors in the policy. There are many things that are included in the policy environment regarding the geographical, cultural characteristics of a region and demographic variables. In addition constellation or global events can also be a political environment that is important in influencing policy. Act's policies covered by the values of each trying to influence policy in order to load output policies espoused values of each policy. The struggle is the essence of the political process among groups to influence the impartiality conditions.
\end{abstract}

Keywords: Diversity, Management, Policy, Formulation Process, Joint Regulation.

\section{Introduction}

Joint Regulation of the Minister of Religious Affairs and Minister of Internal Affairs No. 8 and 9 of 2006 on the guidelines for regional head and deputy regional head in the management of religious harmony, a form of religious harmony and the establishment of houses of worship as oak study of the policies that are causing controversy with regard to the demands of their diverse religious groups in the process of formulation or the time after its ratification. Joint regulation Policy (PBM) No. 8 and 9 of 2006 is an improvement of a joint decree No. 01 of 1969 were on the instructions of the President's decree should be revisited. In the process of its formulation PBM 8 and 9 of 2006 involving five religious assemblies consisting of Indonesian council of ulama (MUI), Indonesian church unity (PGI), KWI and PHDI and Walubi. MUI and PHDI is a group that supports the government's policy, especially on issues requirements for the establishment of places of worship.

The Governing Terms is the necessity of 90 users and support of 60 residents of surrounding communities to be obtained in order to obtain a building permit houses of worship. In addition to the other measures that look quite complicated. MUI and PHDI also based on the opinion of the community who look to have found a number of places of worship yag rise less, based on the real purposes and earnest. Instead the group PGI, KWI and Walubi see this policy did not change from the previous policy, it adds to the complexity of the problems religious community harmony and raises new vulnerability in society. Among the dynamic tension of debate among these interest groups, and various other groups from outside the arena of the process of formulating policies PBM 8 and 9 in 2006 and then approved.

Furthermore, this study wants to analyze the factors that led to the government taking policy PBM 8 and 9 of 2006 and see the substance of policies among which is why the government in the policy settings of the establishment of houses of worship with rule 90 user's 60 community support. In addition, it wants to cannibalize the dynamics that occur among groups of policy actors among which is why the policy is still endorsed by the government, despite the disapproval of the PGI, KWI and Walubi salt formulation poses. By knowing the process of public policy, especially concerning religious harmony in society created by the government, the policy can be detected shortcomings in its purpose to manage diversity. Through detailed analysis of the process of policy formulation PBM 8 and 9 of 2006 will be known where sits the real issue of national diversity. By knowing how policy actors (religious, political, economic) interact in a process of policy formulation, it can be defined forms of interaction between actors.

\section{Literature Review}

Purwanto (2011) in an article entitled public policy in the arena of world civilization is split: understand the politics of ethnicity in public policy formulation, ask several important questions regarding the relationship between the diversity of cultures, religions and beliefs as well as public policy, in particular the process of formulating public policy in the banks is conducted by the government for this. How is the working mechanism of ethnic politics in the process of public policy during this time, and theoretically how public policy 


\section{International Journal of Science and Research (IJSR) \\ ISSN (Online): 2319-7064}

Index Copernicus Value (2013): 6.14 | Impact Factor (2015): 6.391

should respond to the ethnic issue that is increasingly complicated to solve. The perspective of Purwanto, 2011 in clash of interests, where a strong group will win the battle, has implications for the victory of the majority religious group that has the ability to be able to aggregate the interest and value to a public interest. As a consequence of policies to deal with religious diversity are becoming vulnerable to discrimination and marginalized minority groups. Anticipating this needed attention to the ethnic and religious diversity in the process of policy formulation by promoting themes such as positive discrimination or some form of affirmation given to minority groups in the political recognition in which all groups consciously make room for the development of minority groups in all aspects of life. It refers to the adoption of ethnic politics into the process of policy formulation. But that does not mean that adopts ethnic politics into the process of public policy formulation will be no problems. Adoption of ethnic politics would be dangerous because it would increase the danger of the formation of ethnic symptoms.

David Brown (1996), saw some important issues concerning ethnicity, the relationship between ethnicity and among ethnic and country. According to Brown, the most important problems is how to map the relationship between ethnic groups that exist in a country, among them is how the shape of ethnicity and the cause of the formation of ethnic politics. According to Brown, there is a variety of forms of ethnicpolitics and ethnic tensions that occur in almost all countries of Asia-states, but sometimes loyalty to ethnicity and ethnic rivalry between cannot be explained clearly. Ethnic conflict even among issues intertwined historical, cultural, social, economic and political environment. So, according to Brown, the causes of the ethnic conflict is the biggest problem to be solved. Ethnicity even consist of some form associations that pursue economic benefits and political benefits. Ethnicity may sometimes occur among others in language, religion and way of life. If the concept of ethnicity is attached to the concept of the state, required attention to primordial perspective of the ethnic dimension, particularly to resolve the difficulties in making the relations between different ethnic groups as well as how to create a sort of immunity ones when rubbing against the activities of the state. The solution is a picture of cultural nationalism as a plural society.

In the context of all Indonesian, plurality of the Indonesian people in the reform era and the era of openness in all aspects of life concerning religious and cultural diversity when analyzed further been followed by their two problematic aspects. First, from the aspect of cultural diversity and religious values, have tended to the formation of patterns of community interaction is patterned ethnoreligious. The second plurality in the social and political aspects seen their forms of institutionalization of religion. Two pre-conditions that contribute to the amount of government policies aimed at dealing with religious life and instituted a lack of awareness or multiculturalism values that should be instituted in every public policy and be consequent in a pluralistic society. Two aspects of this problematic also found momentum in the presence of diverse demands of religious groups, be it religious, social or political. In the end increased the complexity of the demands of culture, especially religious space within the state administration system.

\section{Methodology}

The study of this paper is the result of literature review from various sources, both the results of previous research, regulations and legislation, and interviews with some relevant sources. The study results are then analyzed qualitatively based studies related theory.

\section{Discussion}

\section{As A Public Policy}

This study from the perspective of public policy can be analyzed in the process of policy formation. There are three models to analyze the process of forming public policy. The first, try to look at the policy formation model of the model group. Public policy in the model group is the result of the struggle of interests among various groups of individuals, each pursuing different interests, but the salty one is forced to form a coalition with groups whose interests can be customized (Dye, 1972). The second is the elite models in the process of policy formation, which refers to Dye (1972) to understand the implications on the elitism of public policy, namely that the state policy is essentially not so much reflect the wishes of the people, but is part of the desire of the elite. Elite model also shows that a small group or a few people who ruled not represent typical of the mass of the governed.

Public policy in this context does not reflect the demands of society in general, but rather highlight the values of the interests of a group of people in power. Changes in public policy are more patchy (incremental). Therefore, change and innovation in public policy are only possible as a result of the redefined values of the elite which was conducted by the elite themselves. The analysis also allows the use of institutional models. Focus our attention to the establishment of institutional policies lies in the analysis of the organizational structure of government (Islamy 2001 in Dwiyanto, 2008). This is because the activities of politics centered on government institutions such as the legislature, executive and judiciary, in the central government, national, regional and local. In connection with that then authoritatively state policy formulated and implemented on the institutions of the government. There is a very strong relationship between the state policy and government institutions. Here are attempting to build a scheme of public policy theory and its use in this research.

From the result of drawing a line in the above frameworks can be made as follows: the first concerns the actors and the value of the above policies, if mapped will consist of four division actor is the majority religion, religious minorities, secular groups and parties of the country. The policy value as the values of religion and ideology is a value pursued by each group of the actor. Are said to be a fight between groups of religious identity, values and symbols of each in a given country. 


\section{International Journal of Science and Research (IJSR) \\ ISSN (Online): 2319-7064}

Index Copernicus Value (2013): 6.14 | Impact Factor (2015): 6.391

Table 1: The mapping of concept and usefulness in research

\begin{tabular}{|c|c|c|c|}
\hline No & Concept & Usefulness in research & $\begin{array}{c}\text { Informatio } \\
n\end{array}$ \\
\hline 1 & Group model & $\begin{array}{c}\text { Seeing the group dynamic actor } \\
\text { with Centered Society } \\
\text { Explanation }\end{array}$ & \\
\hline 2 & Elite model & $\begin{array}{c}\text { See the dynamics of the elite } \\
\text { with the analysis of State } \\
\text { centered Explanation }\end{array}$ & \\
\hline 3 & $\begin{array}{c}\text { Institutional } \\
\text { Model }\end{array}$ & Analyzing the state institutions & \\
\hline
\end{tabular}

Table 2: The mapping of actors, goals and action taken

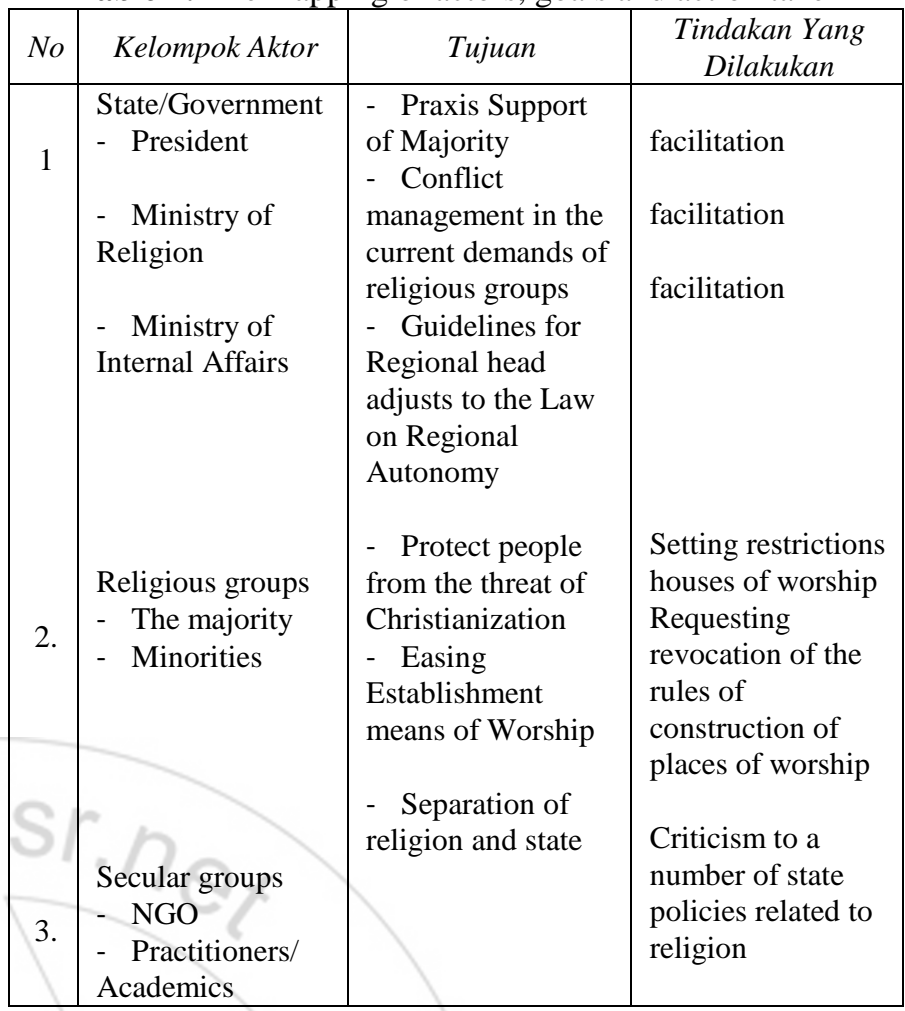

Each group will always try to make the values and interests can be accommodated by the state. The second, from the analysis of state-centered explanation shows that actors of the policy in the public sphere composed of the President ordered to revise the previous policy, and the two relevant ministers, the Minister of Interior and Minister of Religious Affairs and the level echelon are Research Agency Ministry of Religion, Director General of the political unity of the nation and the Ministry of Internal Affairs.

Actors in other religious groups such as the Director General of the Christian community, Catholic, Hindu and Buddhist, each of which tend to be passive. This attitude considering the willingness of the revision is a direct order from the President. The third explanation of the analysis centered society, there are religious organizations such as the MUI group representing Islam, a group representing Christian PGI, KWI representing the Buddha. Each group has values that are trying to be fought in the arena of policy formation process which has been facilitated by the state (government). From Christian groups, there is a desire to liberalize the establishment of houses of worship in order to create easiness for church groups (denominations) were plentiful and varied. While the Islamic party which is represented by the MUI group, there is a desire to control the establishment of houses of worship in order to protect humanity from the threat of Christianization. Based on the above theoretical framework, try to map a group of actors, values and action in Table 2 .

One of the efforts that must be made by the state is to provide a safe public space for the creation of deliberative communication for all groups of citizens. It is expected to contribute to shape good policy, not based on rationality considering the sentiments of faith-based and nondiscriminatory for minorities.

\section{Policy Formulation Process}

There are three crucial issues that are debated in the process of formulating PBM 8 and 9 of 2006, namely the harmonization of policies PBM by 1945 , especially Article 29 which gives the freedom to regulate the issue of religious freedom. This is when associated with the article in the PBM which requires the support of the citizens of 60 people who proved through identity cards and their users by 90 users. Nonetheless, the process of discussion has shown that the democratic process by providing a space for dialogue for religious leaders. There are 11 meetings facilitated by the Ministry of Religious Affairs for approximately 6 months.

Debates and group dynamics in groups on the government look to follow the MUI group thinking and PHDI, but it seems that a great emphasis on the security aspects and the order made by the government eventually gave birth to a policy that is worth Praxis. This refers to the Hefner (2007: 3) that due to the government of the countries recently hit by conflicts traumatized by the conflict, then sometimes it is a policy priority to overcome immediate problems associated with the conflict suffered. Many of these policies Diana Hefner paranoia Praxis.

From the aspect of policy making also showed their dominance interpretation of majority religions, namely the MUI and PHDI which is accommodated a group of more importance by the government and does not satisfy the group PGI, KWI, and Walubi the neglect of some argument developed. This is because the majority group dominance with a variety of arguments (from some interview with correspondents like MUI KH. Ma'ruf Amin) shows that the majority religions dominate the group PGI and KWI which is focused on the aspects of philosophy. Abandonment of the argument - the rational arguments of groups PGI, KWI and Walubi, because the field is a philosophical frame proposed by the PGI and KWI according to the majority group should experience translating it back. Research group studying results and a review of internal MORA Interior Ministry show different things with the arguments clamp PGI, KWI and Walubi.

Can be said to have taken the form of domination between the majority towards the minority, especially in the policy establishment of houses of worship. Public opinion is also held by the majority religious group. Then the process of policy formulation arena the scene of the majority group to subordinate minority groups. Although the process of policy 


\section{International Journal of Science and Research (IJSR) \\ ISSN (Online): 2319-7064}

Index Copernicus Value (2013): 6.14 | Impact Factor (2015): 6.391

formulation PBM 8 and 9 of 2006 did not refuse to communicate between groups of actors, but the communication is not yet in the form of deliberative communication, so that output is still to be seen taking the form of domination of one group against another group. As if the majority is a determinant of whether or not a house of worship should be built. A policy should also be open to the aspirations of minority groups, anytime and anywhere.

\section{Conclusion}

Forms of interaction of actors in the policy formation process can be said to take the form of domination of one group against another group. Based on some of the facts found in the study area: First, in the process of policy formation logic of the government look to follow the logic of thinking of the majority religion, the Second, the fight in the making of public policy has been won by majority religions that pro policies PBM, due to minorities, as well as the secular national shortage of influence in this process and access to power, and a third, opinion regarding the public space that is also controlled by the majority, that is, on issues concerning the construction of places of worship. The arena formulation process eventually became the arena of the majority to subordinate its religious minorities. This study shows that the argument MUI group and the government seem to be more oriented to the practical value of the policy, and in some argumentation seen their/anxieties and prejudices. Group PGI, KWI and Walubi even more ideal no oriented policy. Policy-oriented diversity management Praxis value is feared will lead to separatist dimensions of multiculturalism or pluralism divided (Fragmented Pluralism). Government neglect of the rational arguments put forward by the PGI and supports practical value MUI can be understood when linked to the government's strong desire on the practical support of the majority religious groups intensified the social, economic and political at the beginning of the reform era (1999-2006).

\section{References}

[1] Amin Ma'ruf, 2011, MUI Chairman / Member of Presidential Advisory Council for Religious Harmony / Drafting Team Envoy MUI, March.

[2] Brown, David.1996. The State and Ethnic Politics in Shouteast Asia: New York: Routladge.

[3] Depag RI, 2008. The book Socialization SKB Minister of Religious Affairs, Attorney General and Minister of Home Affairs, No. 3 of 2008 on Warning and Command To devotees, Member and / or the Board of Ahmadiyah Indonesia (JAI) and Citizen Indonesia, Jakarta: Research Agency and Training Ministry of RI.

[4] Depdag RI.2008. Books FAQ Joint Regulation of the Minister of Religion and the Minister of Home Affairs No. 9 and 8 of 2006 on Guidelines Task Regional Head / Deputy Head of the Maintenance of Religious Harmony Within and Empowerment FKUB, Jakrta: DG Kesbangpol.

[5] Dye, Thomas R. 1972. Understanding Public Policy, New Jersy : Prentice Hall.

[6] Dwiyanto, Agus. 2008. Public Bureaucracy Reform in Indonesia, Yogyakarta : Gadjah Mada University Press.
[7] Hefner, Robert.W. (Ed) 2007, Politics Multiculturalism, Sues National Reality, Yogyakarta: Kanisius.

[8] Islamy, Irfan, 2001. The principles of state policy formulation. Jakarta: Earth Literacy.

[9] Ministry of RI. 2006. Handbook Joint Regulation of Religious Affairs and Minister of the Interior No. 9 and 8 of 2006 on Guidelines Task Regional Head / Deputy Head of the Maintenance of Religious Harmony Within and Empowerment FKUB, Jakarta: PKUB.

[10] Sofyan Efendi,1998. Public Administration and Ethnic Conflict, (Papers), Jakarta: STIA LAN.

[11] Purwanto, Erwan A. 2011. Public Policy in a World That split: understand the politics of ethnicity in the formulation of public policy: JIAN, Vol 1 No. 2, 2011 